\title{
TINJAUAN FIQH MUAMALAH TERHADAP PENERAPAN AKAD DALAM PEGADAIAN SYARIAH
}

\author{
Abida Titin Masruroh \\ Institut Agama Islam Negeri Ponorogo \\ abidatitin@gmail.com
}

\begin{abstract}
Abstrak: Dalam kehidupan tentu manusia melakukan pengelolaan harta milik, salah satunya dapat dilakukan dengan gadai. Dalam gadai utang harus disertai dengan memberikan barang jaminan atas pinjamannya. Benda tersebut hak kepemilikannya tetap pada orang yang menggadaikan, namun disimpan atau dijaga oleh pihak penerima gadai. Akad gadai dapat diterapkan oleh lembaga keuangan swasta maupun pemerintah. Gadai yang biasa disebut rahn masuk dalam ruang lingkup muamalah madiyah. Latar belakang dan tujuan dari penelitian ini adalah mengetahui prinsip pengelolaan harta yang sesuai dengan syariah Islam dan untuk mengetahui penerapan akad gadai dalam prinsip syariah di lembaga keuangan. Hasil dari penelitian ini menyimpulkan bahwa gadai merupakan suatu akad pinjam-meminjam dengan disertai barang yang dijadikan jaminan, dasar hukum gadai terdapat dalam Q.S. Al-Baqarah Ayat 283. Dalam gadai terdapat akad-akad yang diterapkan seperti akad wadi'ah, ijarah, qard, mudharabah, dan ba'i muqayyadah.
\end{abstract}

Kata kunci: Fiqh Muamalah, Pengelolaan Harta, Gadai. 


\section{Pendahuluan}

Dalam kehidupan sehari-hari manusia memerlukan kebutuhan untuk mempertahankan hidup. Untuk memenuhi kebutuhannya manusia harus senantiasa berusaha. Usaha tersebut dapat dipenuhi dengan cara bekerja atau mendirikan usaha. Sehingga dalam melakukan usaha-usaha tersebut tentunya memerlukan pembiayaan maupun kerja sama dengan berbagai pihak seperti lembaga keuangan.

Zaman sekarang peranan lembaga keuangan sangat penting dalam membantu pertumbuhan ekonomi. Lembaga keuangan merupakan suatu instansi yang bergerak dalam bidang keuangan. Terdapat dua jenis lembaga keuangan yaitu lembaga keuangan bank non-bank. Bank Umum, Bank Sentral, dan Bank Perkreditan Rakyat (BPR) merupakan jenis dari lembaga keuangan bank. Sedangkan pegadaian, pasar modal, lembaga pembiayaan, lembaga dana pensiun, perusahaan asuransi, dan koperasi simpan pinjam merupakan jenis dari lembaga keuangan non-bank. Bentuk kegiatan lembaga keuangan adalah menghimpun dan menyalurkan dana ataupun jasa-jasa lainnya yang berhubungan dengan keuangan.

Di Indonesia terdapat dua lembaga keuangan yaitu lembaga keuangan konvensional dan syariah. Lembaga keuangan konvensional adalah lembaga keuangan yang usahanya dilakukan secara konvensional dengan menerapkan sistem bunga. Sedangkan lembaga keuangan yang usahanya dilakukan menurut syariat-syariat Islam dengan menerapkan sistem bagi hasil disebut lembaga keuangan syariah.

Salah satu contoh lembaga keuangan adalah pegadaian. Dalam pegadaian menawarkan banyak produk, salah satu produk yang paling dikenal adalah akad gadai. Dalam pegadaian terdapat akad gadai konvensional dan akad gadai syariah. Menerapkan akad yang sesuai dengan syariat-syariat agama Islam seharusnya lebih dipilih oleh umat muslim. Rahn termasuk dalam ruang lingkup muamalah madiyah. Muamalah madiah adalah muamalah yang bersifat kebendaan adalah benda yang halal, benda yang dapat mendatangkan kemaslahatan bagi manusia. Benda dapat diperjualbelikan untuk mendapatkan keuntungan dan ridha dari Allah SWT.

Gadai merupakan salah satu dari perjanjian pinjam meminjam. Lembaga keuangan yang melakukan akad gadai bisa meliputi lembaga swasta maupun lembaga pemerintah.

\section{Metode Penelitian}

Metode penelitian yang digunakan adalah metode kualitatif. Dalam metode ini penulis menganalisis konsep yang berupa kajian pustaka. 
Kajian pustaka diperoleh dari sumber rujukan terpercaya, seperti buku, jurnal, skripsi, tesis.

\section{Pengertian Gadai}

Secara bahasa, gadai (al-rahn) memiliki arti al-habs dan al-tsubutb yaitu penahanan dan penetapan. Ada pendapat lain dalam mengartikan rahn, rabn adalah terkurung atau terjerat. ${ }^{1}$ Sedangkan seacra istilah banyak pengertian tentang gadai. Rahn merupakan suatu perjanjian dengan fasilitas pembiayaan yang dapat diberikan oleh suatu lembaga maupun perorangan dengan penyerahan barang untuk dijadikan agunan. Rahn adalah menjaminkan barang yang memiliki nilai menurut pandangan hukum agar pemilik barang tersebut bisa mendapatkan utang. ${ }^{2}$ Rabn atau gadai adalah penyerahan barang sebagai jaminan untuk mendapatkan pinjaman dana. ${ }^{3}$

Menurut Ulama fiqih terdapat beberapa definisi tentang rahn. Ulama Mazhab Maliki mengartikan Rahn sebagai suatu harta yang dijadikan sebagai agunan utang yang memiliki sifat mengikat pemiliknya. Ulama Mazhab Hanafi mengartikan rahn sebagai barang dijadikan jaminan serta mungkin juga dijadikan untuk membayar utang baik secara keseluruhan maupun sebagian pada pemberi utang. Sedangkan ulama Mazhab Syafi'I dan Mazhab Hanbali mengartikan rabn sebagai suatu akad yang memberikan barang sebagai agunan yang dapat juga dijadikan sebagai pelunasan utang apabila pemilik barang tidak sanggup membayar utangnya. ${ }^{4}$

Dari pengertian gadai dapat diambil ciri-ciri rahn yaitu adanya suatu benda atau barang yang dijadikan sebagai agunan, barang agunan yang digadaikan dapat ditebus dengan melunasi pinjaman, dan nilai barang agunan akan menentukan besaran jumlah pinjaman yang akan diberikan.

\section{Dasar Hukum Gadai}

Dalam syariat Islam gadai diperbolehkan sesuai dengan landasan hukum yang terdapat dalam Qur'an Surat Al-Baqarah ayat 283.

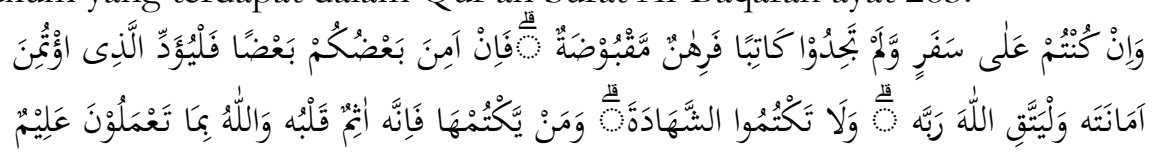

\footnotetext{
${ }^{1}$ Hendi Suhendi, "Fiqh Muamalah, Cet Ke-8," Jakarta: PT Raja Grafindo Persada (2013): 105.

${ }^{2}$ H Syukri Iska, Sistem Perbankan Syariah Di Indonesia Dalam Persperktif Fikih Ekonomi (Fajar Media Press, 2020), 180.

3 Ahmad Subagyo, Kamus Istilah Ekonomi Islam (Elex Media Komputindo, 2013), 338.

${ }^{4}$ Sutan Remy Sjahdeini, Perbankan Islam Dan Kedudukannya Dalam Tata Hukum Perbankan Indonesia (Pustaka Utama Grafiti, 1999), 76.
} 
Artinya: "Dan jika kamu dalam perjalanan sedang kamu tidak mendapatkan seorang penulis, maka hendaklah ada barang jaminan yang dipegang. Tetapi, jika sebagian kamu mempercayai sebagian yang lain, hendaklah yang dipercayai itu menunaikan amanatnya (utangnya) dan hendaklah dia bertakwa kepada Allah, Tuhannya. Dan janganlah kamu menyembunyikan kesaksian, karena barangsiapa menyembunyikannya, sungguh, hatinya kotor (berdosa). Allah Maha Mengetahui apa yang kamu kerjakan.” (QS. Al-Baqarah ayat 283) ${ }^{5}$

\section{Tujuan dan Manfaat pegadaian}

Prinsip pengelolaan harta yang sesuai dengan syariat Islam dalam menyediakan fasilitas dan pelayanan bagi masyarakat umum merupakan karakteristik dari rahn. Dalam pegadaian barang-barang berharga dapat dijadikan agunan untuk mendapatkan pinjaman uang. Tujuan dari pegadaian adalah melalui pengelolaan harta, pegadaian ikut serta melaksanakan program dan kebijaksanaan pemerintah dalam bidang bidang ekonomi dan pembangunan; pencegahan praktek ijon; pada rabn, memiliki efek jaring pengaman sosial dengan prinsip bebas bunga; dan dengan syarat yang relatif mudah dapat membantu orang-orang yang membutuhkan pembiayaan. ${ }^{6}$

Sedangkan manfaat pegadaian yaitu bagi pemberi gadai. Jika dibandingkan dengan kredit perbankan, manfaat utama pegadaian yaitu ketersediaan dana dengan mekanisme yang relatif sederhana dan cepat. Selain mendapat manfaat utama, pemberi gadai juga mendapatkan manfaat lainnya, yaitu terdapat pihak yang berpengalaman dan dapat dipercaya dalam penaksiran nilai barang agunan. Serta tempat yang aman dan dapat dipercaya oleh pemilik barang agunan untuk penitipan barangnya.

Sedangkan bagi perusahaan gadai. Manfaat yang diharapkan perusahaan gadai sesuai dengan jasa yang dilakukannya adalah mendapatkan penghasilan yang bersumber dari sewa dana pinjaman dan biaya atas jasa tertentu yang akan dibayarkan oleh pemberi gadai. Serta perusahaan gadai juga melaksanakan prosedur dengan cara sederhana kepada masyarakat yang membutuhkan pembiayaan dan juga merupakan misinya sebagai salah satu BUMN yang bergerak dalam bidang pembiayaan. $^{7}$

\section{Rukun dan Syarat Gadai}

\footnotetext{
${ }^{5}$ R I Kemenag, “Al-Quran Dan Terjemahannya," Karya Toha Putra (1998).

6 Andri Soemitra, Bank \& Lembaga Kenangan Syariah (Prenada Media, 2017), 407-408.

${ }^{7}$ Bustari Muktar, Bank Dan Lembaga Kenangan Lain (Prenada Media, 2016), 278-279.
} 
Rukun gadai ada empat yaitu barang yang digadaikan, utang, dua orang yang berakad yaitu pemberi gadai dan penerima gadai, dan shighat. ${ }^{8}$ Rukun dan hal-hal yang terdapat dalam gadai harus memenuhi syariat Islam. Marbun adalah objek yang dijadikan jaminan. ' Kriteria marhun adalah barang yang secara hukum sah untuk dijadikan sebagai barang jaminan. Marbun dapat diperjualbelikan, memiliki manfaat, jelas, milik pihak pemberi gadai, harta yang dapat dipindahkan, dan tidak bersatu dengan harta yang lain. Mushannif menerangkan tentang batasan barang yang dijaminkan dalam gadai yaitu bahwa setiap barang yang sah diperjualbelikan, maka barang tersebut boleh dijadikan jaminan dalam beberapa utang. Beberapa utang diartikan oleh Mushannif adalah mengecualikan tanggungan berupa barang-barang, maka akad gadai menjadi tidak sah apabila barang itu menjadi tanggungan, seperti barang pinjaman, barang ghasaban dan barang-barang yang dipertanggungkan. ${ }^{10}$

Barang jaminan dapat berupa barang bergerak maupun barang tidak bergerak. Jenis barang jaminan yang berupa barang bergerak, adalah sebagai berikut: barang-barang perhiasan yaitu semua jenis perhiasan yang dibuat dari emas, perak, intan dan mutiara; barang-barang elektronik meliputi TV, leptop, kulkas, radio, VCD/DVD, HP, dan lainlain; kendaraan seperti sepeda, motor, mobil; barang-barang rumah tangga; mesin seperti mesin jahit, mesin motor kapal; tekstil; dan barangbarang lain yang dianggap mempunyai nilai seperti surat berharga, baik yang berbentuk saham, obligasi, maupun surat berharga dalam bentuk lainnya. ${ }^{11}$

Marbun bih adalah dana yang diperoleh oleh nasabah setelah memberikan jaminan kepada pihak penerima gadai. ${ }^{12}$ Syarat dari marbun bih adalah dain, tsabit, luzum atau ailun ila al-luæum, dan ma'lum. Hak piutang harus jelas, utang harus diketahui dan jelas oleh kedua belah pihak, utang yang tetap dan dapat dimanfaatkan, dan utang memungkinkan untuk dibayar.

Berikut adalah penjelasan dari syarat marbun bib: pertama, dain adalah harta yang dijadikan tanggungan karena beberapa sebab seperti hutang. Kedua tsabit, hutang (dain) disyaratkan harus tsabit. Tsabit adalah hutang yang sudah wujud menjadi tanggungan. Ketiga, luzum atau ailun

\footnotetext{
8 Ahmad bin Umar Asy-Syathiri, “Al-Yaqut An Nafis Fi Madzhab Ibn Idris” (Jeddah: Alamul Ma'rifah, 1989), 201.

${ }^{9}$ Subagyo, Kamus Istilah Ekonomi Islam, 272.

10 Abu Hazim Mubarok, "Fiqh Idola Terjemah Fathul Qorib," Jawa Barat: Mu'jizat (2013): 17.

11 Panji Adam, Fatwa-Fatwa Ekonomi Syariah: Konsep, Metodologi Dan Implemensinya Pada Lembaga Keuangan Syariah (Amzah, 2017), 287.

12 Subagyo, Kamus Istilab Ekonomi Islam, 272.
} 
ila al-lusum adalah dain yang telah wujud atau ada bersifat final dan mengikat atau tidak bisa dibatalkan. Keempat, ma'lum yaitu hutang harus diketahui. ${ }^{13}$

Aqid ada dua yaitu pemberi gadai dan penerima gadai. Pihak-pihak yang terdapat dalam gadai yaitu pertama adalah pihak yang memberikan jaminan gadai dan kedua adalah pihak yang menerima jaminan gadai. Pihak pertama terdiri dari unsur perorangan atau lembaga yang memberikan agunan berupa benda bergerak untuk dijadikan jaminan kepada pihak penerima gadai. Sedangkan pihak kedua berasal dari perorangan atau badan hukum seperti bank, pegadaian, atau lembaga keuangan lainnya yang memiliki piutang. ${ }^{14}$

Syarat pihak-pihak yang terlibat dalam gadai adalah orang yang telah baligh, berakal, dan layak melakukan transaksi rabn, karena rabn merupakan salah satu pembiayaan. Shighat berupa ijab dan qabul. Jiab adalah pernytaan pihak pertama dalam suatu akad. ${ }^{15}$ Sedangkan qabul adalah penerimaan dari pihak kedua dalam suatu akad. ${ }^{16}$ Shighat didasarkan pada kerelaan hati dari pihak yang terlibat.

\section{Sumber Pendanaan}

Pegadaian adalah lembaga keuangan yang tidak diperbolehkan menghimpun dana secara langsung dari nasabah dalam bentuk simpanan. Maka untuk memenuhi kebutuhan dananya, pegadaian memiliki sumbersumber dana yaitu sebagai berikut: modal sendiri, penyertaan modal dari pemerintah, pinjaman jangka pendek dari lembaga perbankan, pinjaman jangka panjang yang berasal dari Kredit Lunak Bank Indonesia, dan dari masyarakat melalui penerbitan obligasi.

Aspek syariah tidak hanya diterapkan dalam sistem operasionalnya saja, pembiayaan yang diberikan kepada nasabah harus diperoleh dari sumber-sumber yang tidak mengandung unsur riba. Dalam hal ini, seluruh pembiayaan murni berasal dari modal sendiri ditambah dengan modal pihak ketiga dari sumber yang dapat dipertanggungjawabkan. Pegadaian telah melakukan kerjasama dengan Bank Muamalat sebagai pemberi dana. ${ }^{17}$

\section{Macam-Macam Rahn}

\footnotetext{
13 Tim Laskar Pelangi, "Metodologi Fiqih Muamalah: Diskursus Metodologis Konsep Interaksi Sosial-Ekonomi” (Kediri: Lirboyo Press, 2013), 115-120.

${ }^{14}$ Suadi Amran, Ekesekusi Jaminan Dalam Penyelesaian Sengketa Ekonomi Syariah (Jakarta: Kencana, 2019), 135-136.

15 Subagyo, Kamus Istilab Ekonomi Islam, 161.

16 Ibid., 323.

17 Soemitra, Bank \& Lembaga Keuangan Syariah, 423-424. 
Macam rahn dibedakan menjadi 2 yaitu pertama, rabn iqar adalah barang agunan tetap dikuasai dan dimanfaatkan oleh nasabah, hanya dipindahkan kepemiliknannya. Konsep ini lebih mirip kepada konsep fidusia. Dalam konsep ini, wujud fisik dari barang agunan masih dapat digunakan dan dikuasai oleh pemberi fisusia, yang diserahkan hanya hak kepemilikan barang jaminannya saja.

Contohnya adalah Ahmad memiliki utang kepada Asih dengan jumlah Rp. 4.800.000,00. Dengan jumlah utang tersebut Ahmad menjaminkan motor secara rabn iqar, namun motor tersebut masih dikuasai dan digunakan oleh Ahmad.

Kedua, rahn hiyazi. Macam ini sangat mirip dengan konsep gadai. Perbedaannya dengan rahn iqar yaitu jika rahn iqar yang diserahkan adalah hak kepemilikan atas barangnya, sedangkan pada rabn biyazi yaitu penerima gadai dapat menguasai barang agunan dan hak kepemilikannya. Dalam gadai barang yang dapat dijadikan agunan adalah barang atau benda bergerak maupun tidak bergerak. Penerima gadai dapat mengambil manfaat barang agunan deangn menanggung biaya pemeliharaan dan perawatannya. Dalam gadai, barang bergerak yang dapat dijadikan jaminan khusunya adalah kendaraan bermotor dan emas.

Contohnya adalah Ahmad memiliki utang pada Asih dengan jumlah Rp. 4.800.000,00, sebagai jaminan Ahmad menggunakan motornya secara rahn hiyazi. Sehingga motor tersebut diserahkan pada Asih. $^{18}$

\section{Perbedaan Pegadaian Konvensional dan Pegadaian Syariah}

Secara umum, perbedaanya dilihat melalui segi aspek manajemen dan administrasinya. Pertama, tanpa bunga dan halal. Dalam pegadian syariah tidak mungkin menerapkan biaya pinjaman yang digunakan oleh pegadaian konvensional. Penentuan keuntungan dari pegadaian syariah adalah pada besarnya nilai barang yang disimpan dengan pengeluaran biaya yang benar-benar terjadi oleh penerima gadai. Sedangkan Wasis Juhar berpendapat bahwa bunga dalam gadai adalah keuntungan dari pegadaian konvensional. Sehingga pendapatan pegadian konvensional sumber pokoknya dari bunga tersebut. Dari penjelasan tersebut dapat dilihat bahwa nilai pembiayaan relatif bersaing antara pegadaian konvensional dan pegadaian syariah. Perbedaan lainnya adalah pegadaian syariah harus melakukan usahanya dengan halal, tidak diperbolehkan membiayai usaha yang terkandung hal yang diharamkan dan tidak sesuai syariat Islam.

18 Djoko Muljono, "Buku Pintar Akuntansi Perbankan Dan Lembaga Keuangan Syariah” (2017): 238-239. 
Kedua, pengambilan kelebihan lelang barang jaminan. Lelang barang jamiann di pegadian syariah, hasil penjualan tersebut jika ada kelebihan, maka sisanya akan kembali pada nasabah. Begitu sebaliknya, jika penjualan kurang, maka nasabah harus membayar kekurangan dari penjualan tersebut. Sedangkan di pegadaian konvensional, apabila penjualan terdapat sisa maka tidak akan dikembalikan pada nasabah. Akan tetapi digunakan untuk kegiatan usaha lain yang menjadi milik penerima gadai.

Ketiga, keanekaragaman jenis barang jaminan yang akomodatif. Deddy Kusdedi berpendapat, dalam pegadaian konvensional barang yang dapat dijadikan sebagai jaminan hanya jenis barang bergerak. Namun barang jaminan tersebut tetap memiliki nilai jual dan tidak menyalahi ketentuan hukum. Adapun dalam pegadaian syariah, barang jaminan dapat berupa benda bergerak maupun tidak bergerak yang penting dapat diperjualbelikan.

Keempat, pengawasan oleh DPS dan DSN-MUI. Mengawasi sistem operasional dan mengawasi produknya agar sesuai dengan nilainilai agama Islam merupakan tugas dari Dewan Pengawas Syariah (DPS). Dalam menjalankan fungsi-fungsinya sebagaimana yang telah diatur pada Surat Keputusan Direksi Perum Pegadaian, DPS wajib mematuhi fatwa DSN. Untuk dapat menumbuhkan kepercayaan masyarakat tentang pegadaian syariah merupakan fungsi keberadaan DPS. Sementara itu, dalam pegadaian konvensional jelas tidak dikenal DPS.

Kelima, Basyarnas dan Peradilan Agama merupakan lembaga penyelesaian perselisihan. Dengan berlakunya UU No. 03 Tahun 2006 tentang Perbankan Syariah. Pada pegadaian syariah alternatif penyelesaian perselisihan dilakukan melalui Peradilan Agama atau Basyarnas. Adapun penyelesaian sengketa di pegadaian konvensional dilakukan melalui Peradilan Umum. ${ }^{19}$

Perbedaan secara ringkas antara pegadaian syariah dan pegadaian konvensional yang dapat dilihat pada tabel berikut ini.

\begin{tabular}{|c|l|l|}
\hline No & \multicolumn{1}{|c|}{ Pegadaian Syariah } & \multicolumn{1}{|c|}{ Pegadaian Konvensional } \\
\hline 1. & $\begin{array}{l}\text { Tidak mengenal sistem bunga } \\
\text { dan objek-objeknya halal. }\end{array}$ & $\begin{array}{l}\text { Penerapannya menggunakan } \\
\text { sistem bunga. }\end{array}$ \\
\hline 2. & $\begin{array}{l}\text { Kelebihan penjualan barang } \\
\text { jamiann akan dikembalikan } \\
\text { pada nasabah. }\end{array}$ & $\begin{array}{l}\text { Kelabihan penjualan barang } \\
\text { jaminan tidak dikembalikan } \\
\text { pada nasabah. }\end{array}$ \\
\hline 3. & $\begin{array}{l}\text { Jaminan benda bergerak } \\
\text { maupun tidak bergerak. }\end{array}$ & Jaminan benda bergerak saja. \\
\hline
\end{tabular}

19 Ade Sofyan Mulazid, Kedudukan Sistem Pegadaian Syariah (Prenada Media, 2016), 2934.

8 Abida Titin Masruroh - Tinjauan Fiqh Muamalah 


\begin{tabular}{|c|l|l|}
\hline 4. & $\begin{array}{l}\text { Pengawasan di bawah DPS } \\
\text { dan DSN-MUI. }\end{array}$ & $\begin{array}{l}\text { Tidak dalam pengawasan DPS } \\
\text { dan DSN-MUI. }\end{array}$ \\
\hline 5. & $\begin{array}{l}\text { Penyelesaian sengketa melalui } \\
\text { peradilan agama atau } \\
\text { basyarnas. }\end{array}$ & $\begin{array}{l}\text { Penyelesaian sengketa oleh } \\
\text { peradilan umum. }\end{array}$ \\
\hline
\end{tabular}

Tabel 1. Perbedaan Pegadaian Syariah dan Konvensional.

\section{Sistem Operasional Pegadaian Syariah}

Pertama, nasabah menyerahkan agunan kepada pihak gadai. Agunan itu berupa barang bergerak. Kedua, pembiayaan diaksanakan antara kedua belah pihak. Ketiga, pihak pegadaian melakukan pembiayaan pada nasabh setelah perjanjian disetujui oleh kedua belah pihak dan barang jaminan diterima oleh pihak penerima gadai. Keempat, nasabah melakukan pembayaran ditambah dengan biaya tambahan yang telah disepakati. ${ }^{20}$

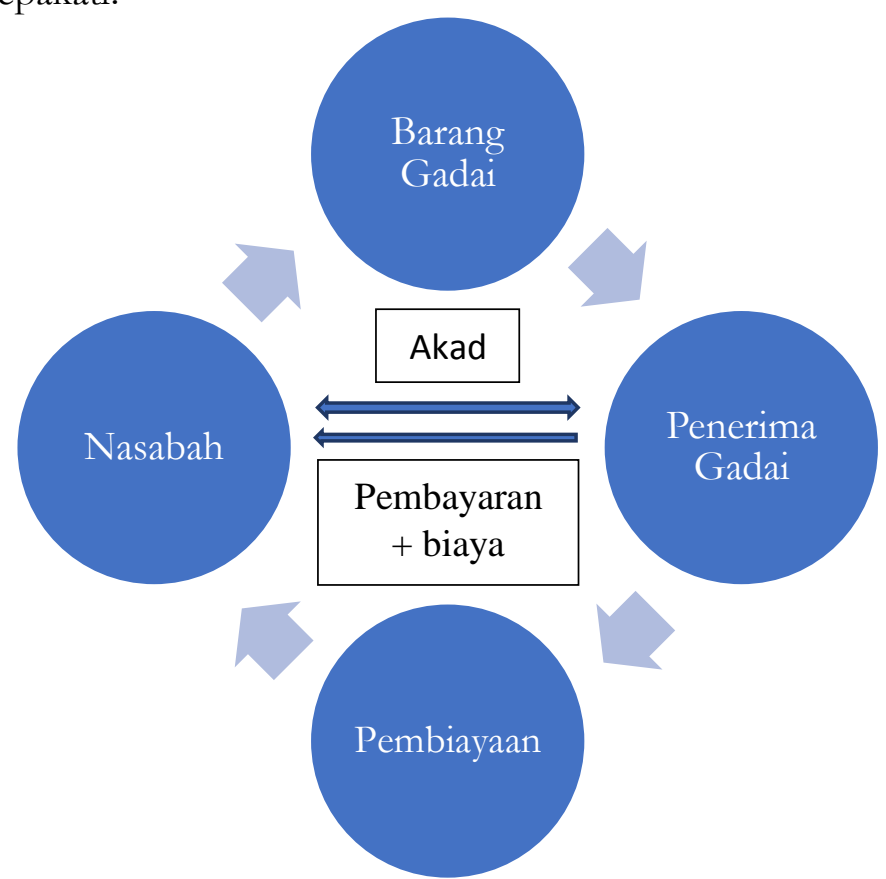

Gambar 1. Sistem Operasional Pegadaian Syariah.

Dalam pegadaian syariah dikenal beberapa pelayanan yang ditawarkan kepada masyarakat yaitu sebagai berikut: pertama, dengan dasar hukum gadai syariah dalam memberikan pembiayaan yaitu berupa pemberian barang jaminan oleh naabah untuk mendapatkan utang

${ }^{20}$ M B A Ismail, Perbankan Syariah (Kencana, 2017), 211-212. 
dengan jumlah yang telah ditaksir sesuai dengan nilai barang yang digadaikan. Kedua, penaksiran nilai barang yaitu pegadaian syariah memberikan jasa penaksiran atas nilai barang yang dijaminkan oleh nasabah. Jasa ini dapat diandalkan oleh lembaga pegadaian sebagai alat penaksiran yang akurat. Ketiga, gadai emas yaitu tempat yang menawarkan keunggulan kualitas dan keaslian dalam penjualan emas yang disertai dengan sertifikat jaminan. Sehingga lebih dapat dipercaya oleh masyarakat. ${ }^{21}$

\section{Hukum Pemanfaatan Barang Gadai}

Menurut Jumhur Ulama, termasuk Imam Syafi'I menghukumi tidak boleh memanfaatkan barang gadai meskipun pemiliknya mengizinkan, karena termasuk dalam mengambil kauntungan dari utang. $\mathrm{Hal}$ itu jelas diharamkan oleh Islam. Imam Syafi'I memperkuat pendapatnya dalam kitab al-Um pada bab "Yang Dapat Merusak Gadai" beliau mengatakan: "manfaat barang gadaian adalah bagi yang menggadaikan, tidak berhak sedikit pun bagi si penerima gadai mengambil manfaatnya ${ }^{22}$

Namun dalam kasus lain, penerima gadai boleh mengambil manfaat barang jaminan gadai jika barang tersebut memerlukan nafkah, seperti hewan ternak. Kebolehan itu hanya sekedar mengganti biaya hidup hewan ternak tersebut dan tidak boleh lebih dari itu. Pendapat itu diperkuat oleh hadits Rasulullah SAW: "Apabila seekor kambing dijadikan barang jaminan, maka si penerima gadai boleh meminum susu kambing yang ada di tangannya senilai ongkos yang ia keluarkan untuk biaya makan dan minum si kambing itu. Jika lebih dari itu, maka dihukumi riba." (HR. Hamar bin Salamah) ${ }^{23}$

Menurut ulama Hanafi, hukum kebolehan memanfaatkan barang jaminan oleh penerima gadai jika hal tersebut diizinkan oleh pemiliknya. Dari pendapat tersebut dapat dipahami, jika pemilik tidak mengizinkannya, maka haram hukumnya untuk memanfaatkan barang jaminan bagi penerima gadai.

Menurut Imam Malik, manfaat atau hasil barang jaminan adalah milik pemberi gadai. Jika penerima gadai memnfaatkan barang tersebut harus sesuai dengan syarat-syarat yang telah disepakati oleh kedua belah pihak. Pendapat Imam Malik sejalan dengan pendapat Imam Syafi'i.

\footnotetext{
${ }^{21}$ Adam, Fatwa-Fatwa Ekonomi Syariah: Konsep, Metodologi Dan Implemensinya Pada Lembaga Keuangan Syariah, 289-290.

22 Sapiudin Shidiq, "Fikih Kontemporer" (Jakarta: Fakultas Ilmu Tarbiyah dan Keguruan UIN Syarif Hidayatullah, 2016, 2016), 261.

${ }^{23}$ Ibid., 262.
} 
Sedangkan menurut Imam Hambali, lebih melihat pada jenis barang yang digadaikan. Jika barang jaminan berwujud binatang yang dapat dijadikan kendaraan, beternak, dan bisa diperah, maka penerima gadai boleh mengambil manfaatnya tanpa seizin dari pihak pemberi gadai. Namun jika barang jamian bukan merupakan hewan, maka penerima gadai boleh mengambil manfaatnya dengan seizin pemiliknya. ${ }^{24}$

Menurut penulis, hukum dibolehkannya mengambil manfaat barang gadai dapat dilihat dari pemeliharaan barang tersebut, dan juga atas perjanjian antara pihak pemberi dan penerima gadai. Namun sudah menjadi persoalan dikalangan masyarakat sekarang, bahwa barang jaminan dapat diambil manfaatnya oleh penerima gadai seperti barang tersebut miliknya sendiri tanpa menghiraukan izin dari pemberi gadai.

\section{Berakhirnya Gadai}

Akad gadai akan berakhir jika terjadi hal-hal sebagai berikut: barang jaminan diserahkan kembali kepada pemiliknya, dengan ikhtiar penerima gadai sendiri, maka akad gadai menjadi batal; pemberi gadai melunasi utangnya; waktu pelunasan telah jatuh pada tempo yang telah disepakati oleh pihak-pihak gadai; barang agunan dijual dengan perintah hakim atau pemberi gadai; pembebasan utang dengan cara apapun, meskipun dengan pemindahan pihak penerima gadai; pembatalan oleh penerima gadai, meskipun tanpa persetujuan dari pihak pemberi gadai; rusaknya barang jaminan; dan pihak pemberi maupun penerima gadai mengambil manfaat barang jaminan untuk sewa, hibah ataupun sedekah. ${ }^{25}$

\section{Strategi Pengembangan Pegadaian Syariah}

Dalam upaya pengembangan pegadaian syariah banyak usaha yang dapat dilakukan oleh lembaga berwenang yaitu usaha untuk membentuk lembaga pegadaian syariah, dapat dilakukan dengan cara mensosialisasikan praktik ekonomi dengan prinsip syariah kepada masyarakat menengah ke bawah yang mengalami kesulitan dalam mendapatkan pinjaman. Untuk itu dibutuhkan kerjasama dari berbagai pihak agar menjadi lebih baik dalam pembentukan pegadaian syariah. Dengan prosedur yang mudah masyarakat akan lebih memilih pegadaian dibanding bank saat mereka membutuhkan pendanaan. Maka hal tersebut dapat menjadikan pegadaian syariah untuk eksis di tengahtengah masyarakat yang membutuhkan dana.

\footnotetext{
${ }^{24}$ Ibid., 263.

${ }^{25}$ H Idri, Hadis Ekonomi: Ekonomi Dalam Perspektif Hadis Nabi (Kencana, 2010), 215216.
} 
Pegadaian syariah dijadikan kegiatan untuk mendukung terciptanya lembaga keuangan yang berbasis syariah, bukan dijadikan sebagai pesaing yang menjadikan lembaga keuangan lainnya mengalami kerugian. Dengan membuat peraturan perundang-undangan yang berlaku secara formal pemerintah dapat mengkoordinir keneradaan pegadaian syariah. ${ }^{26}$

\section{Diskusi Penerapan Akad Dalam Pegadaian Syariah Wadi'ah}

Secara bahasa, wadi'ah diartikan sebagai titipan. Sedangkan menurut istilah, wadi'ah adalah dengan tujuan dijaga sesuatu yang dititipkan oleh pihak pemilik kepada pihak lain. Menurut Hanafiyyah, wadi'ah merupakan suatu barang untuk dijaga secara verbal maupun isyarat, yang kekuasaan diberikan kepada orang lain. Menurut Safi'iyah dan Malikiyah, wadi'ah adalah suatu barang dijaga dengan cara-cara tertentu dengan pemberian perintah dari pemiliknya. Dapat dipahami dari definisi-definisi diatas bahwa wadi'ah adalah suatu akad perintah dari pemilik barang kepada orang lain untuk menjaganya dengan cara-cara sebagaimana mestinya. ${ }^{27}$

Akad wadiah yad al-amanah dan akad wadiah yad adl-dlamanah merupakan macam wadi'ah yang terdapat dalam gadai. Akad wadi'ah yad al-amanah adalah suatu titipan yang oleh pemiliknya dapat diambil setiap saat jika menghendakinya, karakteristik akad ini adalah benda agunan tidak boleh dimanfaatkan oleh penerima gadai dan penerima gadai bertugas dan berkewajiban menjaga barang titipan tanpa mengambil manfaatnya. Sedangkan akad wadi'ah yad adl-dlamanah adalah suatu titipan yang oleh pemiliknya dapat diambil setiap saat jika menghendakinya, karakteristik akad ini adalah barang jaminan boleh diambil manfaatnya oleh penerima gadai dan apabila ada hasil dari pemanfaatan tersebut, maka hasilnya menjadi hak penerima gadai. ${ }^{28}$

\section{Ijarah}

Ijarah berasal dari Bahasa Arab yang artinya upah, sewa, imbalan, atau jasa. Secara bahasa, terdapat beberapa definisi dari ijarah. Ulama Hanafiyah mengartikan ijarah sebagai suatu transaksi dengan memberikan upah atau imbalan terhadap suatu manfaat. Safi'iyah mengartikan ijarah sebagai akad transaksi yang bersifat mubah dan boleh dimanfaatkan dengan adanya suatu imbalan tertentu. Malikiyah berpendapat bahwa ijarah merupakan perpindahan hak milik terhadap manfaat sesuatu yang

\footnotetext{
${ }^{26}$ S Burhanuddin, Aspek Hukum Lembaga Kenangan Syariah (Graha Ilmu, 2010), 182-183.

27 Mahmudatus Sa'diyah, FIQIH MUAMALAH II: Teori Dan Praktik. (UNISNU PRESS, 2019), 13-14.

28 Ahmad Yusnedi, Gadai Syariah (Yogyakarta: Deepublish, 2015), 26.
} 
dibolehkan dalam jangka waktu tertentu dengan imbalan tertentu. Dari pengertian-pengertian diatas, maka ijarah merupakan akad transaksi pemindahan manfaat atas barang maupun jasa dalam jangka waktu tertentu dengan memberikan suatu imbalan, yang tidak disertai dengan pemindahan hak kepemilikan barang yang disewa. Substansi ijarah terletak pada pengambilan manfaat suatu barang dengan pemberian imbalan dalam jangka waktu tertentu. ${ }^{29}$

Dalam gadai akad ini berbentuk murtabin menyewakan fasilitas penyimpanan barang gadai untuk alasan keamanan. Fasilitas tersebut aman dan dapat dipercaya oleh nasabah. Murtabin akan mendapatkan upah dari penyewaan tersebut. Akad ini diterapkan karena lembaga pegadaian menyediakan tempat penyimpanan yang memadai. Dalam akad ijarah besaran fee harus disepakati di awal dan dinyatakan dalam bentuk nominal bukan bentuk presentase. ${ }^{30}$

\section{Qard}

Secara bahasa qard berarti potongan atau terputus. Qard merupakan kewajiban pengembalian pokok pinjaman dana tanpa imbalan sesuai dengan jangka waktu yang telah disepakati kedua belah pihak. ${ }^{31}$ Bank Indonesia berpendapat bahwa qard adalah suatu akad pinjaman wajib dikembailkan sesuai dengan jumlah pinjaman dari bank kepada pihak tertentu yang. ${ }^{32}$

Dalam gadai akad ini, diperuntukkan untuk konsumtif yang dibuat oleh kedua belah pihak yang bertujuan untuk mendapatkan uang tunai melalui transaksi harta benda. Dalam hal ini, penerima gadai yang telah merawat dan menjaga barang jaminan akan memperoleh upah dari pemberi gadai. Pembebanan biaya selain biaya administrasi tidak diperbolehkan pada akad ini. ${ }^{33}$

\section{Mudharabah}

Mudharabah berasal dari lafaz al-Drarb fi al-ard yang artinya perjalanan untuk berdagang. Menurut ulama fiqh mudharabah adalah suatu akad dimana pemilik harta memberikan modal kepada seseorang untuk

\footnotetext{
${ }^{29}$ M H Harun, Fiqh Muamalah (Muhammadiyah University Press, 2007), 122.

${ }^{30}$ Subagyo, Kamus Istilab Ekonomi Islam, 162.

${ }^{31}$ Nur Wahid, Multi Akad Dalam Lembaga Kenangan Syariah (Deepublish, 2019), 60.

32 Sunarto Zulkifli, Panduan Praktis Transaksi Perbankan Syariah (Zikrul Hakim, 2003), 26.

33 Mardani Mardani, "Aspek Hukum Lembaga Keuangan Syariah Di Indonesia" (Prenada Media, 2015), 177.
} 
dikelola dan laba dibagi antara kedua belah pihak sesuai dengan kesepakatan. ${ }^{34}$

Dalam gadai akad ini dimaksudkan untuk pembiayaan dengan tujuan memberikan modal usaha. Besaran modal yang diberikan sesuai dengan taksiran barang jaminan. Akad ini merupakan akad kerja sama dengan kesepakatan bagi hasil dari keuntungannya. Penerima gadai juga akan mendapatkan upah dari perawatan atau penjagaan barang jaminan.

\section{Bai Muqayyadah}

Bai muqayyadah biasa disebut dengan barter. Merupakan jual beli dengan transaksi pertukaran barang dengan barang. Akad ini bersifat produktif yang diberikan kepada nasabah, seperti pembelian peralatan kantor dan modal. Dalam hal ini, akad jual beli barang atau modal kerja sesuai yang diinginkan oleh pemberi gadai. Barang jaminan dapat berupa barang yang dapat diambil manfaatnya oleh kedua belah pihak. ${ }^{35}$ Besarnya pembiayaan ditentukan oleh harga barang yang sudah ditaksir oleh pihak penerima gadai. Penerima gadai akan mendapatkan upah atas biaya adimistrasi dan biaya pemeliharaan barang jaminan.

\section{Kesimpulan}

Berdasarkan uraian materi diatas, maka disimpulkan bahwa gadai adalah suatu perjanjian pinjam meminjam antara kedua belah pihak disertai dengan barang agunan. Dalam pegadaian syariah yang diterapkan adalah akad wa'diah, ijarah, qard, mudharabah, dan bai muqayyadah.

Dalam wa'diah terdapat dua jenis yaitu Akad wadi'ah yad al-amanah dan akad wadi'ah yad adl-dlamanah. Pada gadai akad ijarah berbentuk murtabin menyewakan fasilitas penyimpanan barang gadai. Sedangkan di pegadaian akad qard, diperuntukkan untuk konsumtif yang dibuat oleh kedua belah pihak yang bertujuan untuk mendapatkan uang tunai melalui transaksi harta benda. Dan akad mudharabah dimaksudkan untuk pembiayaan dengan tujuan memberikan modal usaha. Serta akad bäi muqayyadah diterapkan pada gadai bersifat produktif yang diberikan kepada nasabah, seperti pembelian peralatan kantor dan modal.

\footnotetext{
34 Soemitro Andri Soemitro, Hukum Ekonomi Syariah Dan Fiqh Muamalah Di Lembaga Keuangan Dan Bisnis Kontemporer (Prenadamedia Group, 2019), 107.

${ }^{35}$ M Nur Rianto Al Arif, "Lembaga Keuangan Syariah: Suatu Kajian Teoretis Praktis" (Pustaka Setia, 2012), 278.
} 


\section{Daftar Pustaka}

Adam, Panji. Fatwa-Fatwa Ekonomi Syariah: Konsep, Metodologi Dan Implemensinya Pada Lembaga Keuangan Syariah. Amzah, 2017.

Andri Soemitro, Soemitro. Hukum Ekonomi Syariah Dan Fiqh Muamalah Di Lembaga Keuangan Dan Bisnis Kontemporer. Prenadamedia Group, 2019.

Al Arif, M Nur Rianto. "Lembaga Keuangan Syariah: Suatu Kajian Teoretis Praktis." Pustaka Setia, 2012.

Burhanuddin, S. Aspek Hukum Lembaga Kenangan Syariah. Graha Ilmu, 2010.

Harun, M H. Fiqh Muamalah. Muhammadiyah University Press, 2007.

Idri, H. Hadis Ekonomi: Ekonomi Dalam Perspektif Hadis Nabi. Kencana, 2010.

Iska, H Syukri. Sistem Perbankan Syariah Di Indonesia Dalam Persperktif Fikih Ekonomi. Fajar Media Press, 2020.

Ismail, M B A. Perbankan Syariah. Kencana, 2017.

Kemenag, R I. “Al-Quran Dan Terjemahannya." Karya Toha Putra (1998).

Mardani, Mardani. "Aspek Hukum Lembaga Keuangan Syariah Di Indonesia." Prenada Media, 2015.

Mubarok, Abu Hazim. "Fiqh Idola Terjemah Fathul Qorib.” Jawa Barat: Mu’jizat (2013).

Muktar, Bustari. Bank Dan Lembaga Kenangan Lain. Prenada Media, 2016.

Mulazid, Ade Sofyan. Kedudukan Sistem Pegadaian Syariah. Prenada Media, 2016.

Muljono, Djoko. "Buku Pintar Akuntansi Perbankan Dan Lembaga Keuangan Syariah" (2017).

Pelangi, Tim Laskar. "Metodologi Fiqih Muamalah: Diskursus Metodologis Konsep Interaksi Sosial-Ekonomi." Kediri: Lirboyo Press, 2013.

Sa'diyah, Mahmudatus. FIQIH MUAMALAH II: Teori Dan Praktik. UNISNU PRESS, 2019.

Shidiq, Sapiudin. "Fikih Kontemporer." Jakarta: Fakultas Ilmu Tarbiyah dan Keguruan UIN Syarif Hidayatullah, 2016, 2016.

Sjahdeini, Sutan Remy. Perbankan Islam Dan Kedudukannya Dalam Tata Hukum Perbankan Indonesia. Pustaka Utama Grafiti, 1999.

Soemitra, Andri. Bank \& Lembaga Kenangan Syariah. Prenada Media, 2017.

Suadi Amran. Eksekusi Jaminan Dalam Penyelesaian Sengketa Ekonomi Syariah. Jakarta: Kencana, 2019.

Subagyo, Ahmad. Kamus Istilab Ekonomi Islam. Elex Media Komputindo, 2013.

Suhendi, Hendi. "Fiqh Muamalah, Cet Ke-8." Jakarta: PT Raja Grafindo Persada (2013). 
bin Umar Asy-Syathiri, Ahmad. "Al-Yaqut An Nafis Fi Madzhab Ibn Idris.” Jeddah: Alamul Ma'rifah, 1989.

Wahid, Nur. Multi Akad Dalam Lembaga Kenangan Syariah. Deepublish, 2019.

Yusnedi, Ahmad. Gadai Syariah. Yogyakarta: Deepublish, 2015.

Zulkifli, Sunarto. Panduan Praktis Transaksi Perbankan Syariah. Zikrul Hakim, 2003. 